\title{
Studies on the Metabolism of Aspergilli
}

\author{
Part II. Nitrogen Balance during Endogenous Respiration and Effects \\ of Glucose, Amino Acids and Inhibitors on Endogenous Respiration
}

\author{
By Takeji Mizunuma \\ Noda Institute for Scientific Research, Noda-shi, Chiba-ken
}

Received July 1, 1933

\begin{abstract}
Studies were made on the endogenous respiration of Aspergillus sojae K.S. Observing the changes of Kjeldahl-nitrogen in each fraction of the mycelial components, the author concluded that pool amino acids, bound amino acids, protein, nucleic acids and nucleotides covered whole of the nitrogenous reserves available for endogenous respiration in the mycelia. A study was carried out on the effect of preincubation with glucose or amino acids on endogenous respiration. Stimulation of either oxygen uptake, protein breakdown or ammonia formation was observed during respiration of the mycelia incubated with a suitable concentration of azide, 2,4-dinitrophenol, potossium fluoride, monoiodoacetic acid or ethylenediaminetetraacetic acid. Ammonia formation accompanied with endogenous respiration seemed to proceed inversely by the influence of energy yielding reaction.
\end{abstract}

\section{INTRODUCTION}

As described in the previous paper ${ }^{1)}$, the modes of endogenous respiration of Aspergillus sojae K.S. changed according to the C:N ratio of the culture medium. The substrates of endogenous respiration of the mycelia grown on the medium of low $\mathrm{C}: \mathrm{N}$ ratio were found largely to be pool amino acids and protein. It was also suggested that nucleic acids and nucleotides in the mycelia might be a part of the substrates. On the other hand, when the mold was grown on the medium of high $\mathrm{C}: \mathrm{N}$ ratio, the dissimilation of endogenous carbohydrate or lipid preceded the utilization of those nitrogenous reserves.

In the present paper, the results of biochemical analysis are described in respect to the changes during the endogenous respiration of the individual nucleotides and Kjeldahl-nitrogen in the fractions of mycelia.

\footnotetext{
1) T. Mizunuma, This Journal, 27, 88 (1963)
}

The effects on the endogenous respiration of glucose, amino acids and various inhibitors are also described.

\section{MATERIALS AND METHODS}

\section{Microorganism.}

The organism used was Aspergillus sojae K.S.

\section{Incubation and Procedures.}

Deionized water was used throughout the experiments. Procedures for the cultivation of mold and for the manifestation of endogenous respiration were the same as described in the previous paper except that the mycelia were washed with water in place of buffer solution.

The mold was grown on either Medium B containing $10 \mathrm{~g}$ glucose or Medium $\mathrm{C}$ containing $2 \mathrm{~g}$ glucose. The basal components of the medium were

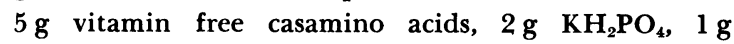
$\mathrm{MgSO}_{4} \cdot 7 \mathrm{H}_{2} \mathrm{O}$, a trace of $\mathrm{FeSO}_{4} \cdot 7 \mathrm{H}_{2} \mathrm{O}$ and $\mathrm{ZnSO}_{4} \cdot 7 \mathrm{H}_{2} \mathrm{O}$, $12 \mathrm{~g}$ agar and $1000 \mathrm{ml}$ water. The $\mathrm{pH}$ was adjusted to 5.8 to 6.0 .

3. Analytical Methods.

The fractionation and analytical methods of the 
mycelial components described in the previous paper were partially modified as follows. The mycelia washed with ice cold water were homogenized with an appropriate amount of water and the homogenates were stored at $2^{\circ} \mathrm{C}$ after acidification (pH 2) with dil. HCl. The potassium phosphate buffer solution on which the mycelia were floated during incubation was filtered and similarly stored at $2^{\circ} \mathrm{C}$ after acidification. The ammonia content of the incubated buffer solution and the filtrates of homogenates (heated for $10 \mathrm{~min}$. at $100^{\circ} \mathrm{C}$ ) were determined by indophenol reaction $^{2)}$. Kjeldahl-nitrogen was determined also by

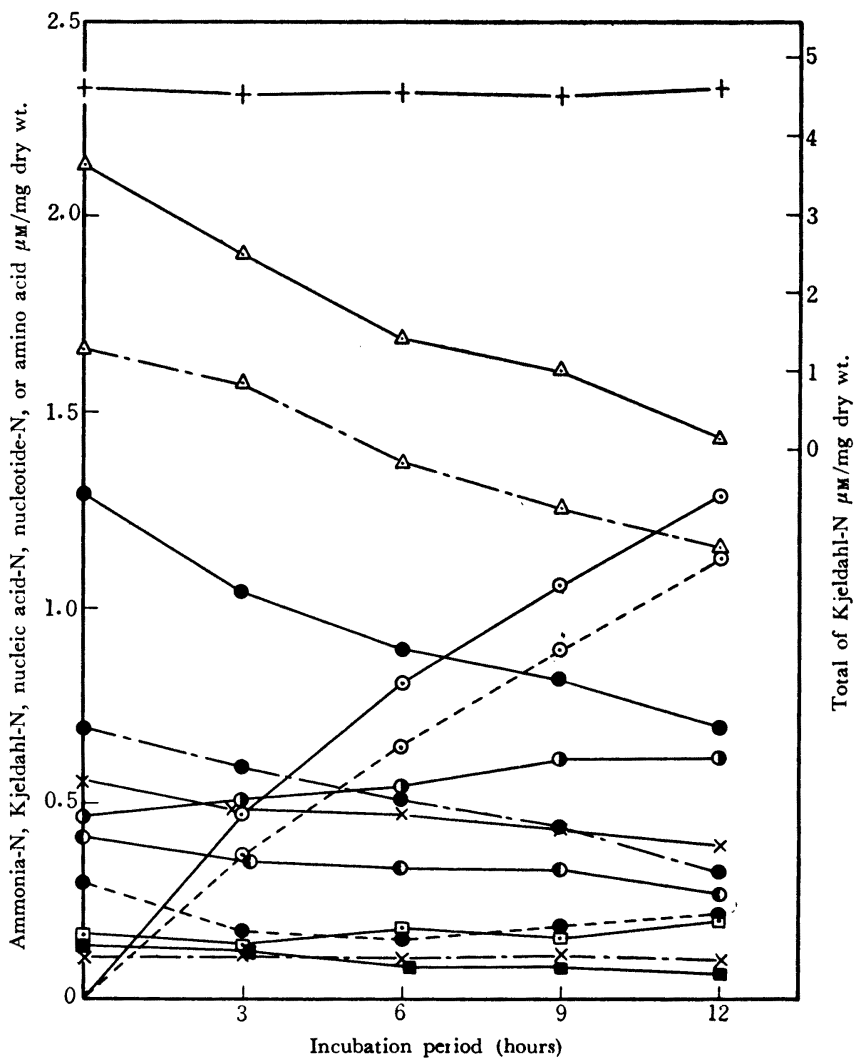

FIG. 1. Changes during Endogenous Respiration of Kjeldahl-Nitrogen Balance and Other Components in the Mycelial Fractions.

Solid lines : Kjeldahl-nitrogen

Dotted lines: Ammonia-nitrogen

Broken lines: Amino acid (not amino acid-N)

$\odot$ : Incubated buffer solution

: Cold TCA fraction

$x$ : Hot TCA fraction

$\triangle:$ TCA insoluble and $\mathrm{NaOH}$ soluble fiaction

[1): Ethanol-ether soluble fraction

(1) Insoluble fraction

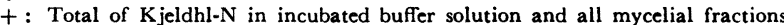
The other symbols are

- Nucleotide-N in cold PCA fraction

The mold was cultured on medium $\mathrm{C}$ for $30 \mathrm{hrs}$. at $30^{\circ} \mathrm{C}$ when nearly maximum growth of 8.95 mg dry weight per mat was attained. The mycelial mats were washed with water and incubated on buffer solution ( $\mathrm{M} / 10, \mathrm{pH} 7.0)$ at $30^{\circ} \mathrm{C}$ for endogenous respiration.

2) B. Lubochinsky and J. Zalta, Bull. Soc. Chim. Biol., 36, 1363 (1954). 
the indophenol reaction after digestion with conc. $\mathrm{H}_{2} \mathrm{SO}_{4}$ about each fraction obtained by the method of Schmidt, Thanhauser and Schneider. As a minor modification, extraction with ethanol-ether was carried out for $18 \mathrm{hrs}$. at 55 to $60^{\circ} \mathrm{C}$.

The methods described in the previous paper were adopted for the fractionation of mycelial components and the determinations of amino acids, protein, total carbohydrates and total reducing sugars in the mycelia, and of total carbohydrates and ninhydrin positive material in the incubated buffer solution.

Nucleotides in cold and hot perchloric acid (PCA) fractions were assayed by measuring O.D. at $260 \mathrm{~m} \mu$.

Separation of individual nucleotides was carried out by the use of anion exchange resin, Dowex-1 (X2) . After treatment with Norit extra, the cold PCA fraction was poured into the column $(1 \times 10 \mathrm{~cm})$ packed with Dowex-1 (formate form). Then, the column was washed with water and eluted with a gradient mixture of formic acid and ammonium formate solutions at a speed of 0.5 to $0.6 \mathrm{ml}$ per min. ${ }^{3)}$ One fraction was $5 \mathrm{ml}$. A chromatogram was made by measuring O.D. at $260 \mathrm{~m}_{\mu}$ of eluted samples. Absorption at $275 \mathrm{~m}_{\mu}$ served as a reference for qualitative determination of the individual nucleotides. A standard chromatography of the mixture of several known nucleotides was carried out in the same way.

\section{RESULTS}

I. Changes during Endogenous Respiration of Kjeldahl Nitrogen Balance in the Mycelial Fractions.

The amounts of Kjeldahl-N of mycelial fractions, namely cold TCA, hot TCA and protein fractions were compared with those of amino acids and nucleotides in the course of endogenous respiration.

As shown in Fig. 1, the total amount of Kjeldahl-N was kept at a constant level; the loss of nitrogen was negligible during respiration. It is seen in Fig. 1 that the major part of Kjeldahl-N in cold TCA fraction consisted of ammonia- and pool amino acid-N while the minor part was nucleotide-N. Kjeldahl$\mathbf{N}$ in hot TCA fraction came from both nucleic acids and amino acids bound with them. Kjeldahl-N content in ethanol-ether soluble fraction changed only to a small extent. On the other hand, from the gradual increases of insoluble nitrogen, it is presumed that the partial synthesis of cell wall material containing the insoluble nitrogen proceeded during respiration.

In order to know the amount of amino acid-N which was not assayed in this experiment, the ratio of amino acids $(\mu \mathrm{M})$ to

TABLE I. A SUMMARY OF GHANGES DURING ENDOgENOUS RESPIRATION OF COMPONENTS IN MYCELIA AND INCUBATED BUFFER SOLUTION
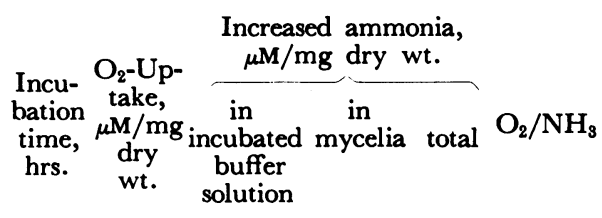

Composition of cold TCA fraction, $\%$ of amino Decom- $\mu \mathrm{M} / \mathrm{mg}$ dry wt. acids to posed* $/ \mathrm{NH}_{3}$ formed amino acids other than ammonia- \&
ammonia- \& nucleotide-N
nucleotide-N
0. 848.9

$\begin{array}{lccc}- & - & - & - \\ 1.76 & 0.357 & -0.133 & 0.224 \\ 4.36 & 0.463 & -0.147 & 0.496 \\ 6.60 & 0.884 & -0.118 & 0.766 \\ 8.42 & 1.121 & -0.087 & 1.034\end{array}$

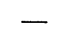

7.9

8.8

8.6

1.36

1.10

0.683

0.93

1.12

0.585

0.438

0.320
0.756

80.9

77.4

77.8

0.649

79.9

0.414

77.3

(on an average) 78.7

Composition of protein fraction $\mu \mathrm{M} / \mathrm{mg}$ dry wt. \% of amino acids to amino Kjeldahl-N K jeldahl-N of protein of protein
fraction $\begin{array}{lll}1.66 & 2.13 \quad 78.0\end{array}$ $1.57 \quad 1.90 \quad 82.6$ $\begin{array}{lll}1.37 & 1.68 & 81.6\end{array}$

$\begin{array}{lll}1.25 & 1.60 \quad 78.2\end{array}$

$1.15 \quad 1.43 \quad 80.5$
(on an average) 80.2

All the conditions were the same as in Fig. 1.

* Decomposed nitrogenous reserves : (Total of decreased Kjeldahl-N of nitrogenous reserves) - (Increased insoluble-N in cell wall material and increased Kjeldahl-N other than ammonia in incubated buffer solution)

3) R.B. Hurbert, H. Schimitz, A.F. Brumm and V.R. Potter, J. Biol. Chem., 209, 23 (1954). 
TABle II. A SUMmaRY OF CHANGes DURING ENDOgenous REspiration OF the Ratio of Total Amount of Individual Amino Acids to TOTAL Nitrogen Contained

\begin{tabular}{|c|c|c|}
\hline \multirow{2}{*}{$\begin{array}{l}\text { Incubation } \\
\text { time, } \\
\text { hrs. }\end{array}$} & \multicolumn{2}{|c|}{$\begin{array}{l}\text { Total of individual* } \\
\text { amino acids, } \\
\times 10^{-2} \mu \mathrm{M} / \mathrm{mg} \text { dry wt. }\end{array}$} \\
\hline & $\begin{array}{l}\text { in cold } \\
\text { TCA sol. } \\
\text { fraction }\end{array}$ & $\begin{array}{l}\text { in cold } \\
\text { TCA insol. } \\
\text { fraction }\end{array}$ \\
\hline 0 & 64.9 & 155.9 \\
\hline 2 & 51.5 & 133.4 \\
\hline 4 & 49.1 & 116.5 \\
\hline 6 & 44.5 & 102.9 \\
\hline 10 & 34.3 & 110.7 \\
\hline
\end{tabular}

IN THEM

\begin{tabular}{|c|c|c|c|}
\hline \multicolumn{2}{|c|}{$\begin{array}{l}\text { Total-N in total** } \\
\text { amino acids, } \\
\times 10^{-2} \mu \mathrm{M} / \mathrm{mg} \text { dry wt. }\end{array}$} & \multicolumn{2}{|c|}{$\begin{array}{l}\% \text { of total of individual } \\
\text { amino acids to total-N } \\
\text { in them }\end{array}$} \\
\hline $\begin{array}{l}\text { in cold } \\
\text { rCA sol. } \\
\text { fraction }\end{array}$ & $\begin{array}{l}\text { in cold } \\
\text { TCA insol. } \\
\text { fraction }\end{array}$ & $\begin{array}{l}\text { in cold } \\
\text { TCA sol. } \\
\text { fraction }\end{array}$ & $\begin{array}{l}\text { in cold } \\
\text { TCA insol. } \\
\text { fraction }\end{array}$ \\
\hline 87.6 & 190.5 & 74.0 & 81.7 \\
\hline 68.0 & 162.4 & 75.7 & 82.2 \\
\hline 62.2 & 140.7 & 78.9 & 82.8 \\
\hline 55.8 & 124.8 & 79.7 & 82.5 \\
\hline \multirow[t]{2}{*}{43.8} & 92.0 & 78.3 & 83.0 \\
\hline & (on an average) & 77.3 & 82.4 \\
\hline
\end{tabular}

* Total of the individual amino acid was calculated from the data in previous paper (Fig. 6).

** The theoretical amount of nitrogen contained in individual amino acid was calculated.

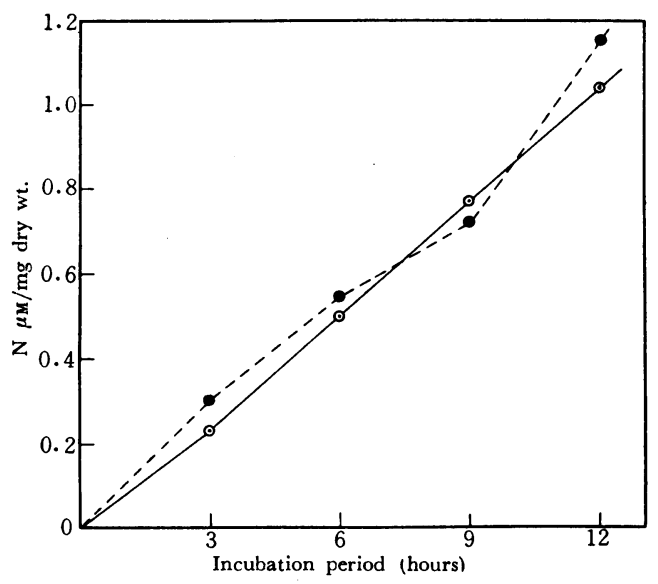

FIG. 2. Corresponding Changes during Endogenous Respiration of Formed Ammonia with KjeldahlNitrogen of the Decomposed Nitrogenous Reserves. The conditions of the mold cultivation and endogenous respiration were the same as in Fig. 1.

$-\odot-:$ : Ammonia formed

- - - : Kjeldahl-nitrogen of the decomposed nitrogenous reserves

Kjeldahl-N $(\mu \mathrm{M})$ in cold TCA and protein fractions was calculated (Table I). Table I shows that the ratio of pool amino acids $(\mu \mathrm{M})$ to Kjeldahl-N $(\mu \mathbf{M})$ other than ammonia- and nucleotide-N was fairly constant in cold TCA fraction at a range from 77.3 to $80.9 \% \quad(78.7 \%$ on an average). The ratio in protein fraction was also fairly constant at a range from 78.0 to $82.6 \%(80.2 \%$ on an average). In another experiment, the ratio of amino acids $(\mu \mathrm{M})$ to amino acid-N $(\mu \mathrm{M})$ during endogenous respiration was calculated by the determination of individual amino acids (Table II).

The above data of Tables I and II indicated that all of Kjeldahl-N other than ammonia- and nucleotide- $\mathrm{N}$ in cold TCA and protein fractions were amino acid- $\mathrm{N}$, that is, Kjeldahl-N in cold TCA fraction was composed of ammonia-, nucleotide- and amino acid-N and $\mathrm{Kjeldahl-N}$ in protein fraction composed of protein constituting amino acidN.

In conclusion, the nitrogenous reserves as the substrates of endogenous respiration in the mycelia were practically composed of pool amino acids, bound amino acids, protein, nucleic acids and nucleotides. In addition, the amount of Kjeldahl-N of decomposed nitrogenous reserves corresponded fairly well with that of ammonia formed (Fig. 2). This indicated that ammonia formed during endogenous respiration was mostly derived from the degradation of the nitrogenous reserves.

II. Changes during Endogenous Respiration of Individual Nucleotides in Mycelia.

Qualitative and quantitative studies were made on the changes during endogenous respiration of individual nucleotide in cold 


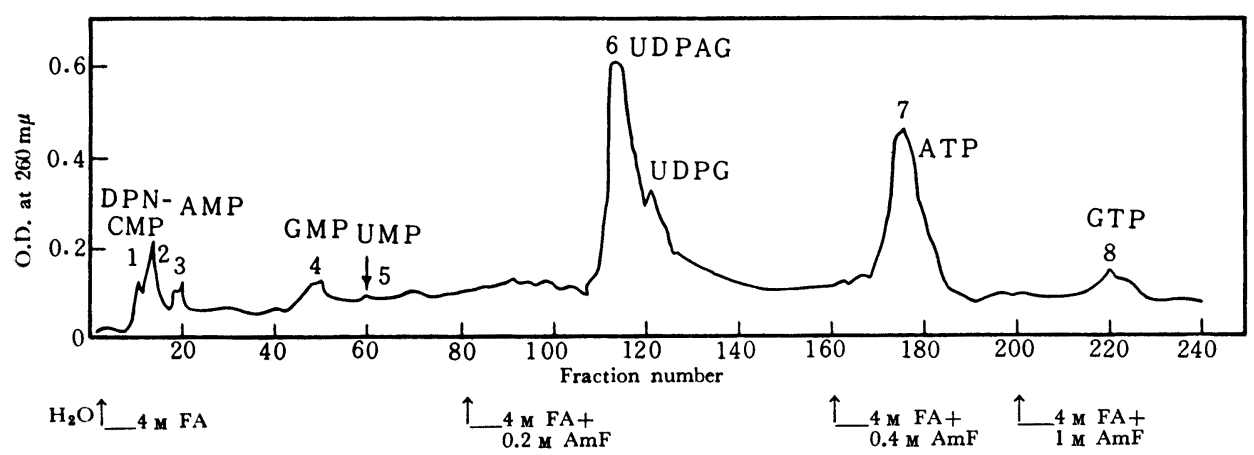

FIG. 3. A Chromatogram of Nucleotides in the Mycelia.

The resin column $(1 \times 10 \mathrm{~cm})$ of Dowex-1 $(\mathrm{X} 2$, formate form) was used for chromatography of nucleotides in the mycelia which were cultured on Medium C for $30 \mathrm{hrs}$. at $30^{\circ} \mathrm{C}$. Almost maximal growth was attained $(8.40 \mathrm{mg} / \mathrm{mat})$. Twenty-four sheets of the mycelia at a time were used for analysis and eluted with mixture of formic acid (FA) and ammonium formate solution $(\mathrm{AmF})$. One fraction of the eluted sample was $5 \mathrm{ml}$.

TABle III. Ghanges DURING Endogenous Respiration of INDIVIdUAL Nucleotides IN THE MYCELIA

Growth medium

Incubation medium

Incubation time, hrs.

Total nucelotides

DPN-CMP

AMP

Unknown

GMP

UMP

UDP-derivatives

ATP

GTP

\section{Medium B}

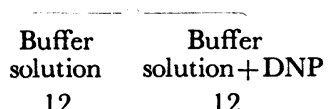

$\overbrace{\begin{array}{c}\text { Buffer } \\ \text { solution } \\ 12\end{array}}^{\text {Medium G }} \begin{gathered}\begin{array}{c}\text { Buffer } \\ \text { solution + DNP } \\ 12\end{array} \\ 12\end{gathered}$

$\begin{array}{lll}0 & 12 & 12\end{array}$

Total O.D. at $260 \mathrm{~m} \mu / 100 \mathrm{mg}$ dry weight

$\begin{array}{llllll}3.23 & 1.59 & 1.49 & 4.28 & 1.98 & 1.83 \\ 0.09 & 0.07 & 0.15 & 0.06 & 0.15 & 0.24 \\ 0.01 & 0.08 & 0.12 & 0.20 & 0.18 & 0.11 \\ 0.03 & 0.00 & 0.06 & 0.08 & 0.04 & 0.04 \\ 0.06 & 0.01 & 0.05 & 0.16 & 0.08 & 0.05 \\ 0.01 & 0.18 & 0.11 & 0.00 & 0.00 & 0.00 \\ 1.81 & 0.82 & 0.69 & 2.25 & 0.95 & 0.99 \\ 1.09 & 0.39 & 0.28 & 1.40 & 0.49 & 0.34 \\ 0.13 & 0.04 & 0.03 & 0.13 & 0.09 & 0.06\end{array}$

Cultured on Medium B or $\mathrm{C}$ for $30 \mathrm{hrs}$. at $30^{\circ} \mathrm{C}$.

Dry weight per mycelial mai was 20.20 and $8.40 \mathrm{mg}$, respectively.

Phosphate buffer solution $(M / 10, \mathrm{pH} 7.0)$ without or with DNP $(\mathrm{M} / 1000)$ was used as incubation medium of the mycelia.

TCA fraction of the mycelia. In Fig. 3 is shown a chromatogram of individual nucleotide in the mycelia. The greater part of nucleotides was composed of adenosine triphosphate (ATP) and uridine diphosphate glucose (UDPG) -uridine diphosphate acetylglucosamine (UDPAG). A trace of diphospho-pyridine nucleotide (DPN)-cytidine monophosphate (CMP), adenosine monophosphate (AMP), guanosine monophosphate (GMP), uridine monophosphate (UMP) or guanosine triphosphate (GTP) was detected.
In Table III are shown the changes during endogenous respiration of these nucleotides before and after incubation of buffer solution without or with 2,4-dinitrophenol (DNP, M/ 1000) for $12 \mathrm{hrs}$. In the presence of DNP, endogenous respiration was promoted to some extent as referred later (section IV). In all cases, the remarkable decreases of ATP and UDPG-UDPAG were observed.

III. Effect of Preincubation with Glucose or Amino Acids on Endogenous Respiration.

As shown in Fig. 4, a larger increase in 


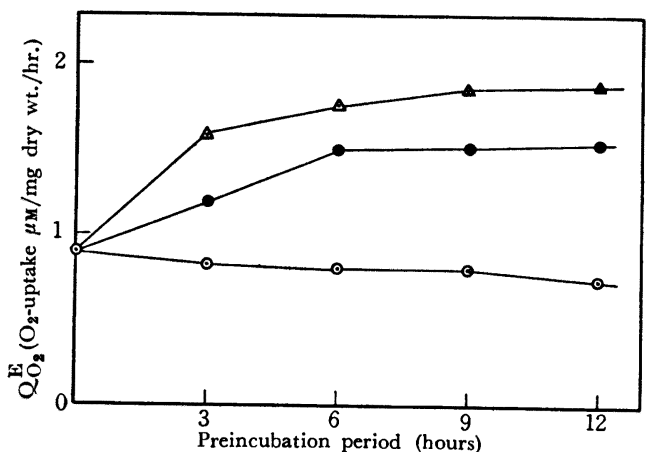

FIG. 4. Effects of Preincubation with Glucose or Casamino Acids on Endogenous Respiration.

Eight sheets of the mycelial mats cultured on Medium C for $37 \mathrm{hrs}$. at $30^{\circ} \mathrm{C}$ were previously incubated on $15 \mathrm{ml}$ of buffer solution with or without $1.8 \%$ glucose or $1.8 \%$ casamino acids at $30^{\circ} \mathrm{C}$, and after being washed twice with water endogenous respiratory ability of the mycelia was measured. Initial dry weight of the mycelia was $5.05 \mathrm{mg}$ per mat.

$-\odot-$ : Incubation on buffer solution

- Incubation on buffer solution with $1.8 \%$ glucose

- - : Incubation on buffer solution with $1.8 \%$ casamino acids

$Q_{\mathrm{O}_{2}}^{\mathrm{E}}$ was observed by the preincubation with casamino acids than with glucose. Preincubation of the mycelia with glucose or casamino acids leads to the increases of total carbohydrates, pool amino acids and protein (Fig. 5) . It is evident that the increase of total carbohydrates in the mycelia does not always cause the maximum enhancement of endogenous respiration.

Table IV shows that the mycelia accumulated large amounts of carbohydrates by the

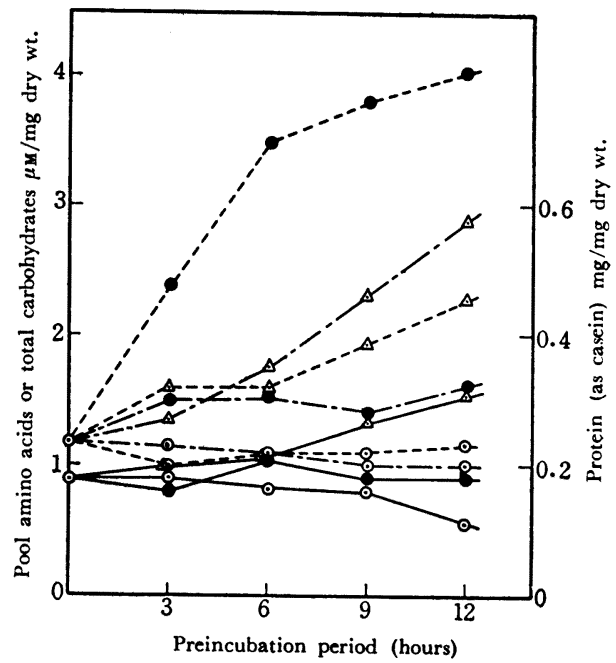

FIG. 5. Effects of Preincubation with Glucose or Casamino Acids on Mycelial Composition.

The conditions of the mold cultivation and incubation of the mycelia with glucose or casamino acids were the same as in Fig. 4.

The symbols, $\odot, \odot$ and $\Delta$, show incubation with buffer, glucose and casamino acids, respectively.

Solid lines : Pool amino acids

Broken lines: Protein

Dotted lines: Total carbohydrates

preincubation with glucose for $6 \mathrm{hrs}$. did not produce ammonia during endogenous respiration, no utilization of nitrogenous reserves being observed. The major substrate of respiration was changed from the nitrogenous reserves to carbohydrate or lipid by the shift of metabolic activities during incubation with glucose.

Table IV. EFfect of Preincubation with Glucose on Ammonia formation DURING ENDOGENOUS RESPIRATION

\begin{tabular}{|c|c|c|c|c|c|}
\hline \multirow{2}{*}{ Incubation medium } & \multirow{2}{*}{$\begin{array}{l}\text { Incubation } \\
\text { time, hrs. }\end{array}$} & \multicolumn{2}{|c|}{$\begin{array}{l}\text { Ammonia formed, } \\
\mu \mathrm{M} / \mathrm{mg} \text { dry wt. }\end{array}$} & \multirow{2}{*}{$Q_{O_{2}}^{\mathrm{E}}$} & \multirow{2}{*}{$\begin{array}{l}\text { Total amino acids, } \\
\mu \mathrm{M} / \mathrm{mg} \text { dry wt. }\end{array}$} \\
\hline & & $\begin{array}{l}\text { in } \\
\text { mycelia }\end{array}$ & $\begin{array}{l}\text { in incubated } \\
\text { buffer solution }\end{array}$ & & \\
\hline \multirow[t]{2}{*}{ Buffer solution } & 0 & 0.39 & 0.10 & 0.39 & 2.21 \\
\hline & 6 & 0.20 & 0.51 & 0.27 & 1.99 \\
\hline \multirow{2}{*}{$\begin{array}{l}\text { Buffer solution* } \\
\text { (after preincubation with } \\
\text { glucose for } 6 \mathrm{hrs} \text {.) }\end{array}$} & 0 & 0.06 & 0.03 & 0.65 & 2.25 \\
\hline & 6 & 0.06 & 0.04 & 0.44 & 2.29 \\
\hline
\end{tabular}

Cultured on Medium C for $36 \mathrm{hrs}$. at $30^{\circ} \mathrm{C}$. Dry weight: $8.20 \mathrm{mg} / \mathrm{mat}$.

* After preincubation with $1.8 \%$ glucose solution for $6 \mathrm{hrs}$. and washing, the mycelia were again incubated on buffer solution at $30^{\circ} \mathrm{C}$. The changes of the amount of $\mathrm{QO}_{\mathbf{2}}^{\mathrm{E}}$, ammonia formed and total amino acids were assayed during the second incubation with buffer solution. 
Table V. EFfects of PReincubation of the Mycelia with Individual AMINO ACIDS ON ENDOGENOUS RESPIRATION

\begin{tabular}{|c|c|c|c|c|c|c|}
\hline $\begin{array}{l}\text { Amino acid } \\
\text { incubated }\end{array}$ & $\begin{array}{l}\text { Dry weight } \\
\text { after pre- } \\
\text { incubation, } \\
\mathrm{mg} / \mathrm{mat}\end{array}$ & $\begin{array}{l}\text { Ammonia } \\
\text { formed, } \\
\mu \mathrm{M} / \mathrm{mg} \text { dry } \\
\text { wt. }\end{array}$ & $\begin{array}{l}\mathrm{Q}_{\mathrm{N}_{2}}^{\mathrm{E}} \text { for } \\
\text { initial } \\
\text { one } \mathrm{hr} \text {. }\end{array}$ & $\begin{array}{l}\text { Pool amino } \\
\text { acids, } \\
\mu \mathrm{M} / \mathrm{mg} \text { dry } \\
\text { wt. }\end{array}$ & $\begin{array}{c}\text { Amino acids } \\
\text { in protein, } \\
\mu \mathrm{M} / \mathrm{mg} \text { dry } \\
\text { wt. }\end{array}$ & $\begin{array}{c}\text { Total } \\
\text { nucleotides } \\
\text { (as RNA-N), } \\
\mu \mathrm{M} / \mathrm{mg} \text { dry } \\
\text { wt. }\end{array}$ \\
\hline Buffer & 7.22 & 0.48 & 0.60 & 0.57 & 1.42 & 0.38 \\
\hline L-Leucine & 8.52 & 0.55 & 0.91 & 0.71 & 1.26 & 0.40 \\
\hline L-Isoleucine & 8.45 & 0.42 & 0.77 & 0.64 & 1.27 & 0.39 \\
\hline L-Phenylalanine & 8.18 & 0.36 & 0.72 & 0.81 & 1.36 & 0.39 \\
\hline L-Aspartic acid & 8.48 & 0.52 & 0.69 & 0.63 & 1.42 & 0.42 \\
\hline L-Alanine & 8.22 & 0.67 & 0.72 & 0.88 & 1.44 & 0.50 \\
\hline L-Valine & 8.12 & 0.53 & 0.97 & 0.77 & 1.38 & 0.39 \\
\hline L-Proline & 8.78 & 0.56 & 0.69 & 0.62 & 1.44 & 0.44 \\
\hline L-Glutamic acid & 8.60 & 0.49 & 0.69 & 0.74 & 1.43 & 0.48 \\
\hline Glycine & 7.85 & 0.94 & 0.71 & 1.00 & 1.20 & 0.34 \\
\hline L-Threonine & 3.22 & 0.65 & 0.81 & 0.85 & 1.18 & 0.38 \\
\hline L-Lysine & 8.02 & 0.56 & 0.39 & 1.00 & 1.21 & 0.36 \\
\hline
\end{tabular}

In Table $\mathrm{V}$ are shown the data of endogenous respiration of the mycelia after preincubation with individual amino acid. The initial $Q_{O_{2}}^{E}$ values were promoted beyond control level except the case of lysine. In the latter case, a latent period was observed before linear oxygen uptake began and subsequently the low initial $\mathrm{Q}_{\mathrm{O}_{2}}^{\mathrm{E}}$ was resulted. The similar situation was also found when the mycelia were preincubated with arginine or histidine. The preincubation of the mycelia with threonine, alanine, glycine or lysine brought about the increase of pool amino acids and also the enhanced formation of ammonia compared with oxygen uptake during endogenous respiration.

IV. Effects of Various Inhibitors on Endogenous Respiration.

In Tables VI and VII are shown the shifts of respiration patterns in the presence of metabolic inhibitors. Oxygen uptake was stimulated to some extent when the mycelia were incubated with a suitable concentration of azide, DNP or ethylenediaminetetraacetic acid (EDTA), whereas suppression was shown by $a, a^{\prime}$-dipyridyl, potassium fluoride $(\mathrm{KF})$ or benzoquinone (BQ).

Degradation of the nitrogenous reserves involving protein and formation of ammonia was more or less stimulated by incubating the mycelia with azide, DNP, deoxypyridoxine, KF, monoiodoacetic acid or EDTA. On the other hand, the consumption of nucleotides or total carbohydrates was unaffected by inhibitors in most cases. Rather, the amounts of total carbohydrates slightly increased in the presence of inhibitors for carbohydrate utilization such as KF or monoiodoacetic acid. These data may suggest the reversible process between metabolic pathways of utilization of carbohydrate-lipid and the nitrogenous reserves.

As shown in Table VIII, the amounts of ninhydrin positive material appeared in incubated buffer solution during endogenous respiration were generally less than $13 \%$ of the consumed total amino acids in the mycelia. That the azide exceptionally enhanced 


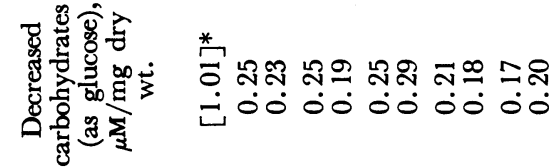

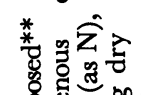

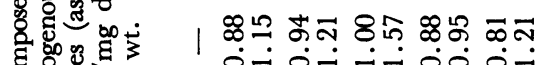
造密

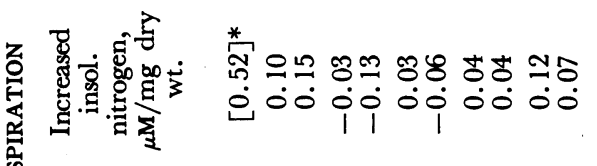

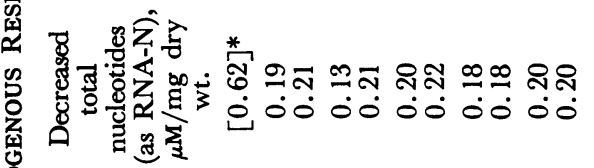
育

z

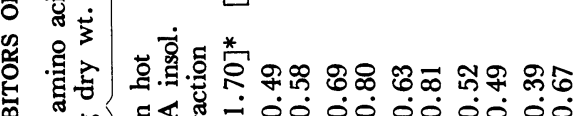

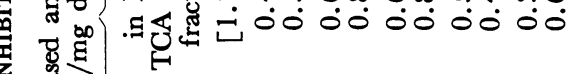

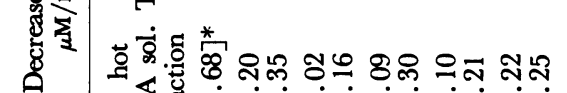
म 造 | कू

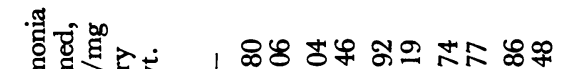

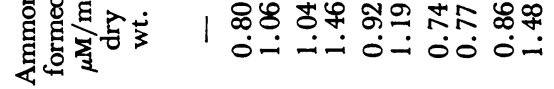
$\dot{s}$ | वैँ । ભำ ถูกิ 00000000000

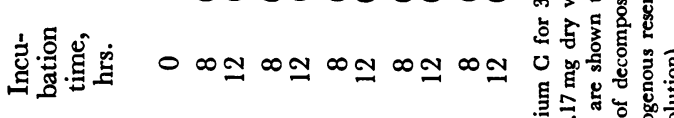

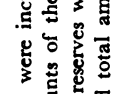

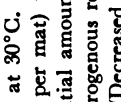
更

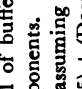

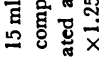

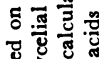

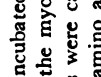

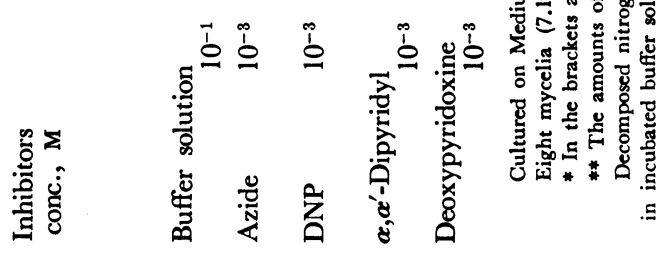

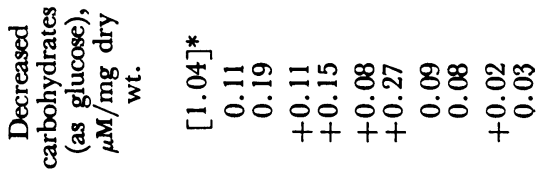
噌器家

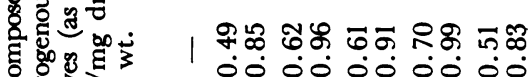

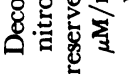

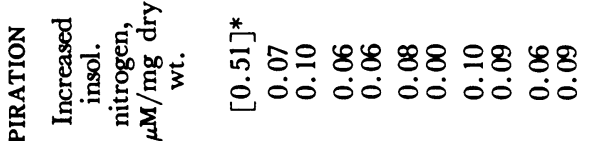
ซ్ $\begin{array}{ll} & \\ 0 & 0\end{array}$

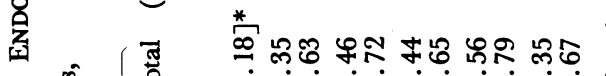
z 灵

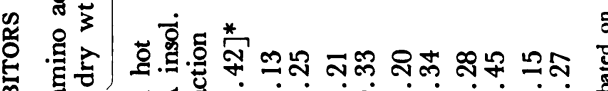

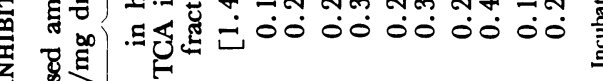

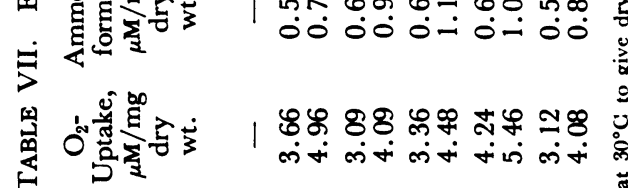
"। $\alpha$ 000000000

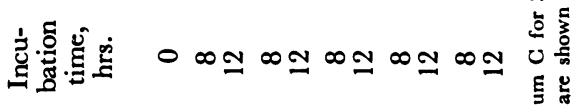

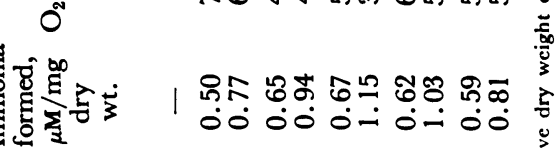

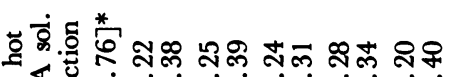
.

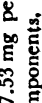

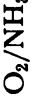
m+ 两

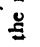

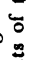

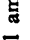


TABLE VIII. AMOUNTS OF SEVERAL COMPONENTS APPEARED IN INCUBATED BUFFER SOLUTION AFTER INCUBATION WITH INHIBITORS

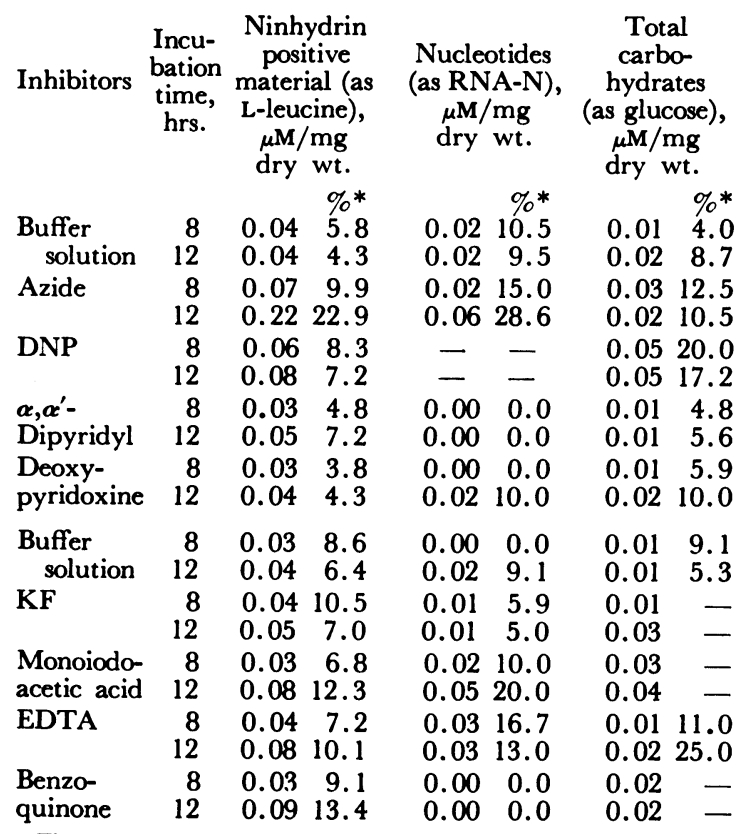

The conditions of the mold cultivation and incubation with inbibitors were the same as in Table VI and VII.

* \% of each component increased in incubated buffer solution to the decreased in the mycelia.

the excretion of ninhydrin positive material was possibly owing to autolysis. The amounts of total carbohydrates or nucleotides appeared in incubated buffer solution were also small as compared with the decreases in the mycelia. It was thus clear that the decreases of nitrogenous and carbohydrate reserves in the mycelia were due to the consumption as the substrates of endogenous respiration which was influenced by the presence of various inhibitors.

\section{DISCUSSION}

Several papers have been published on the substrates of endogenous respiration in bacteria $^{4-8)}$ and other microorganisms ${ }^{9}$. The

4) E.A. Dawes and W.H. Holms, Biochim. Biophys. Acta, 30, 278(1958), 5) R.A.J. Warren, A.F. Elles and J.J.R. Campell, J. Bact., 79, 875 (1960).

6) A.F. Gronlund and J.J.R. Campell, ibid., 81, 721 (1961).

7) C.E. Clifton and J.M. Sobeck, ibid., 82, 252 (1961)

H.H. Ramsey, ibid., $9)$ B.E. Wright and M.L. Ánderson, Biochem. Biophys. Acta, 43, 62
$(1960)$. conditions of preceding cultures were known to change the substrates of endogenous respiration $^{7,10)}$, but no influence was observed in some instances ${ }^{11)}$.

The endogenous respiration of Aspergillus sojae K.S. was influenced by the $\mathrm{C}: \mathrm{N}$ ratio of the culture medium as reported in previous paper ${ }^{1)}$. In the present paper, Fig. 1 and Table I indicated that the considerable amounts of nitrogenous reserves were consumed as the substrates of endogenous respiration, judging from the low $\mathrm{O}_{2} / \mathrm{NH}_{3}$ values and that the nitrogenous reserves were practically composed of pool amino acids, nucleic acid-bound amino acids, protein, nucleic acids and nucleotides. From the above observations and Fig. 2, it is seen that ammonia formed during endogenous respiration was mostly derived from the degradation of pool amino acids, bound amino acids, protein, nucleic acids and nucleotides in the mycelia.

The remarkable decrease of ATP and UDP-derivatives was observed as seen in Table III although the other nucleotides remained unchanged during endogenous respiration. The decrease of UDP-derivatives might relate to cell wall synthesis as suggested by increase of insoluble nitrogen.

It is known that preincubation of resting cells with amino acids leads to either stimulation $^{12)}$ or suppression ${ }^{13}$ ) of endogenous respiration in various kinds of microorganisms. The preincubation of Aspergillus sojae K.S. with amino acids, such as threonine, alanine, glycine or lysine increased the pool amino acids content and resulted in the enhancement of endogenous ammonia formation (Table V). This could be the evidence that the pool amino acids are the direct substrates of endogenous respiration.

\footnotetext{
10) A. Schatz, G.S. Trelaway, V. Schatz and R.R. Mohan, Myco logia, 48, 883 (1956).

11) W.F. Danforth and B.W. Wilson, J. Gen. Microb., 24, 95 (1961).

12) F. Berneim, J. Bact., 44, 533 (1942).

13) S. Ganguly and S.C. Roy, Arch. Biochem. Biophys., 59, 45 (1955).
} 
The studies with inhibitors gave an additional evidence for the pattern of endogenous respiration. The uncouplers of oxidative phosphorylation such as azide and DNP, and the inhibitors for carbohydrate metabolism such as $\mathrm{KF}$, monoiodoacetic acid and EDTA were found to stimulate the breakdown of the nitrogenous reserves involving protein and the formaiton of ammonia during endogenous respiration. Although it has been reported that azide or DNP stimulates endogenous respiration in a certain bacteria ${ }^{14}$, suppression was occasionally observed. It is also known that the breakdown of protein during endogenous respiration requires energy yielding reaction ${ }^{15)}$.

\section{SUMMARY}

1. Pool amino acids, nucleic acids-bound amino acids, protein, nucleic acids and free nucleotides in the mycelia of Aspergillus sojae K.S. practically covered all of the nitrogenous reserves utilizable as the substrates of endogenous respiration and could be degraded to form corresponding amount of ammonia dur- ing endogenous respiration.

2. Utilization of the nitrogenous reserves as the substrates of endogenous respiration was inhibited after preincubation with glucose.

3. Previous incubation of the mycelia with amino acids, especially threonine, alanine, glycine or lysine increased the amount of pool amino acids leading to stimulated formation of ammonia during endogenous respiration.

4. Degradation of the nitrogenous reserves involving protein and formation of ammonia were more or less stimulated by incubating the mycelia with the uncouplers of oxidative phosphorylation (azide and DNP) or the inhibitors for carbohydrate metabolism (KF, monoiodoacetic acid and EDTA).

Acknowledgement. The author wishes to express his sincere gratitude to Prof. K. Arima and Emeritus Prof. K. Sakaguchi of University of Tokyo for their helpful guidance. Grateful acknowledgement is also made to Dr. M. Mogi, Director of this Institute and Dr. H. Ōnishi for their guidance and encouragement throughout the study.

14) F. Bernheim, Science, 120, 430 (1954).

15) J. Mandelstam, Biochem. J., 69, 110 (1958). 